\title{
PELATIHAN PENULISAN DAN PUBLIKASI ARTIKEL ILMIAH MAHASISWA TINGKAT IV JURUSAN TEKNIK ELEKTRO POLITEKNIK NEGERI LHOKSEUMAWE TAHUN 2020/2021
}

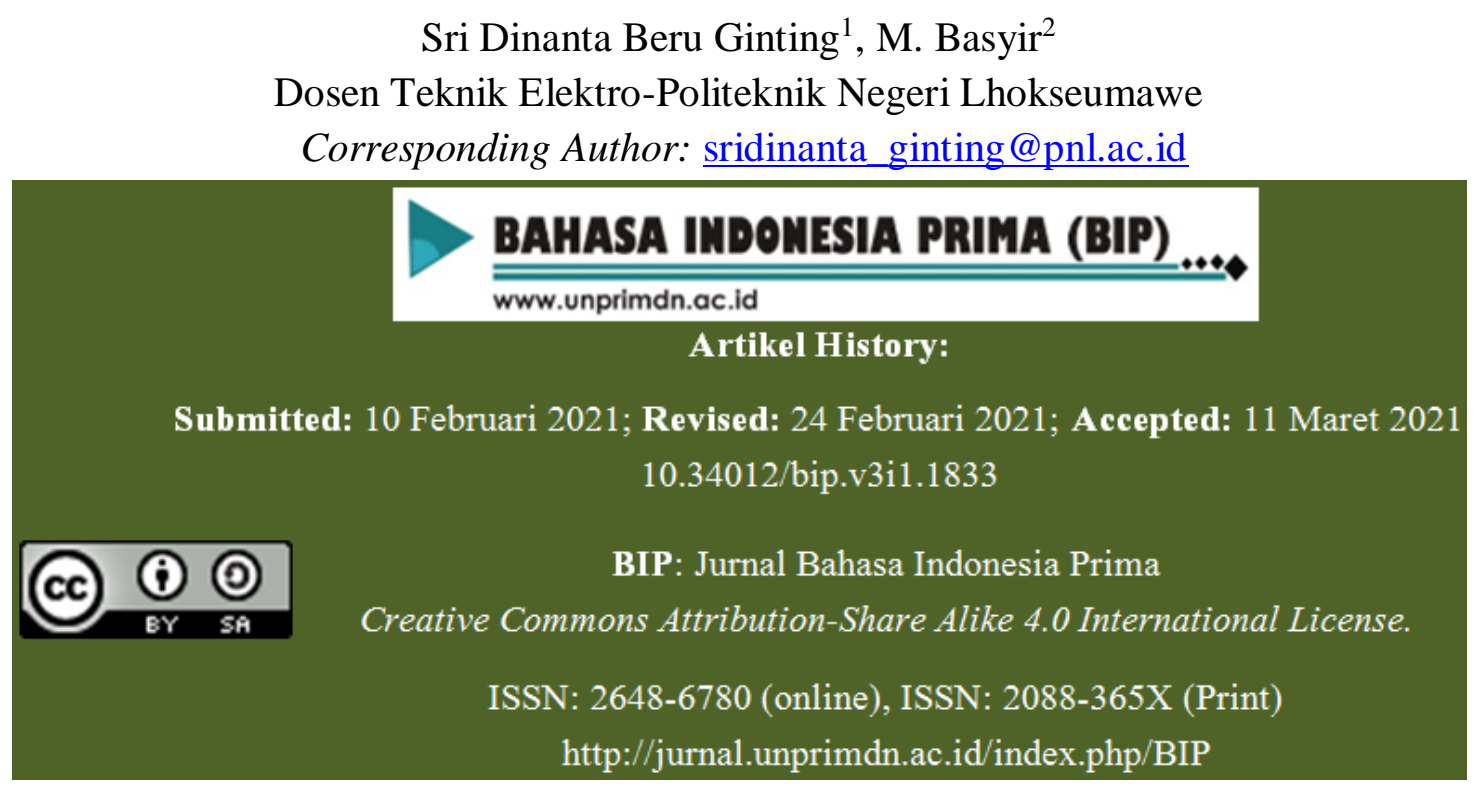

Abstrak- Mahasiswa tingkat akhir wajib untuk menulis artikel ilmiah dan mempublikasi artikel ilmiah berdasarkan SE Ristekdikti No. B/323/B.B1/SE/2019 tentang kewajiban publikasi karya ilmiah program sarjanan, program magister, dan program doktor. Kemudian, artikel ilmiah mahasiswa menjadi satu diantara penilaian di dalam akreditasi program studi oleh BAN-PT pada 9 kriteria, yaitu penilaian di kriteria 8. Atas dasar hal-hal tersebut, dilakukan pemecahan isu, yaitu dengan melaksanakan pengabdian kepada masyarakat dengan Kegiatan Pelatihan dalam Kegiatan Menulis Artikel Ilmiah dan Publikasi Artikel Ilmiah pada Mahasiswa Tingkat IV Jurusan Teknik Elektro Politeknik Negeri Lhokseumawe (PNL). Metode pelaksanaan kegiatan pengabdian ini melalui metode pelatihan, yaitu 1) analisis dan identifikasi kebutuhan pelatihan; 2) merancang desain pelatihan; 3) mengembangkan; 4) penerapan pelatihan. Hasil dari pengabdian masyarakat ini menunjukkan keberhasilan ditunjukkan dari respon positif dalam pelaksanaan kegiatan pelatihan. Selanjutnya, keberhasilan pengabdian masyarakat ini yang berupa pelatihan dengan sasaran kelompok mahasiswa ditunjukkan dari $80 \%$ dari jumlah peserta pelatihan, yaitu dengan rincian, 24 peserta dari 29 peserta telah mampu menulis artikel ilmiah dan mensubmit artikel ilmiah yang disesuaikan dengan template jurnal. Artikel ilmiah ini merupakan luaran dari hasil kegiatan aktualisasi berupa pengabdian masyarakat dengan pelaksanaan Pelatihan Kegiatan Menulis Artikel Ilmiah dan Publikasi Artikel Ilmiah pada Mahasiswa Tingkat IV Jurusan Teknik Elektro Politeknik Negeri Lhokseumawe (PNL) pada 11 - 30 Oktober 2021.

Kata kunci: artikel ilmiah, publikasi, pengabdian, penulisan 


\section{A. Pendahuluan}

Belum optimal kegiatan pembelajaran menulis artikel ilmiah menyebabkan kemampuan mahasiswa belum optimal dalam menulis artikel ilmiah. Pembelajaran tersebut belum optimal karena pelakasanaan pembelajaran pada materi Menulis Artikel Ilmiah masih menggunal model ceramah. Selain itu, mahasiswa masih difokuskan untuk mengenal bentuk artikel ilmiah dan mempraktikkan bagian tertentu dari artikel ilmiah, seperti bagian pendahulan. Namun, belum difokuskan untuk mempraktikkan menulisnya.

Model pembelajaran tersebut membuat mahasiswa belum mampu menulis artikel ilmiah. Padahal, saat ini mahasiswa diwajibkan untuk mempublikasikan artikel ilmiah dari Laporan Tugas Akhir mahasiswa sebagai syarat yudisium. Selain itu, belum optimal kegiatan pembelajaran kegiatan menulis artikel ilmiah menyebabkan kemampuan mahasiswa belum optimal dalam menulis artikel ilmiah mempengaruhi efektivitas proses pembimbingan bagi dosen dan mahasiswa itu sendiri.

Selain disebkan hal-hal tersebut, urgensi dari isu tersebut disebabkan juga adanya kewajibabn mahasiswa tingkat akhir wajib untuk menulis artikel ilmiah dan mempublikasi artikel ilmiah berdasarkan SE Ristekdikti No. B/323/B.B1/SE/2019 tentang kewajiban publikasi karya ilmiah program sarjanan, program magister, dan program doktor. Kemudian, artikel ilmiah mahasiswa menjadi satu diantara penilaian di dalam akreditasi program studi oleh BAN-PT pada 9 kriteria, yaitu penilaian di kriteria 8. Atas dasar hal-hal tersebut, perlu dilakukan gagasa pemecahan isu, yaitu dengan menerapkan model pelatihan dalam kegiatan menulis artikel ilmiah dan publikasi artikel ilmiah pada mahasiswa tingkat IV Jurusan Teknik Elektro Politeknik Negeri Lhokseumawe (PNL). Hal tersebut dilakukan agar gagasan pemecahan isu ini sejalan dengan fungsi ASN dalam Pasal 10 UU Nomor 5 Tahun 2014, yaitu "Pelaksanaan Kebijakan Publik, Pelayan Publik, dan Perekat dan Pemersatu Bangsa". Selanjutnya, , Suyitno (dalam Widayoko, 2019:10) mengemukakan tiga ciri pokok yang membedakan artikel hasil penelitian dengan artikel jenis lain adalah tipe materi, sistematika, dan prosedur penelitian. Materi mencakup substansi prosedur penelitian, temuan penelitian, pembahasan, dan kesimpulan. Selanjutnya, sistematika mencakup kajian pustaka yang menjadi dasar penulisan latar belakang masalah yang ditutup dengan rumusan tujuan, prosedur, temuan, pembahasan, simpulan dan isi. Sementara itu, prosedur penelitian melalui dua cara, yaitu sebelum menyusun laporan penelitian yang bertujuan untuk mendapatkan masukan dan setelah menyusun laporan penelitian yang bertujuan untuk dipublikasi di jurnal ilmiah.

Berkaitan dengan uraian sebelumnya, hal pokok yang perlu diperhatikan di dalam penyusunan hasil menurut Istadi (dalam Slameto, 2016:52), sebagai berikut.

a. Tampilkan data hasil penelitian dalam bentuk grafik atau tabel, mana yang lebih tepat, pilih salah satu apakah dalam bentuk grafik atau tabel, tidak boleh duplikasi antara grafik dan tabel.
b. Grafik atau gambar biasanya dipresentasikan dalam file jenis TIFF (.tif), JPEG (.jpg). atau Postcript (.eps), 
satu file per gambar. Kualitas grafik harus jelas dan baik, sehingga ketika diedit di jurnal setelah dikecilkan ukurannya, font size tetap dapat terbaca. Tebal garis harus mencukupi.

c. Hasil penelitian harus signifikan dan mempunyai kontribusi baru bagi ilmu pengetahuan serta menyelesaikan permasalahan. Deskripsikan penyelesaian permasalahan secara jelas.

\section{B. Metode Pelaksanaan Aktualisasi Pelatihan}

\section{1) Waktu dan Tempat Pelaksanaan}

Kegiatan pelatihan dilaksanakan dari tanggal 10 Oktober 2020 sampai 30 Oktober 2020 melalui aplikasi zoom. Kegiatan pelatihan ini diikuti oleh 29 peserta dari mahasiswa Jurusan Teknik Elektro Politeknik Negeri Lhokseumawe. Berikut ini adalah rincian pelaksanaan pelatihan.

Rincian Kegiatan Pelatihan Penulisan

\section{Artikel Ilmiah dan Publikasi Artikel}

\section{Ilmiah}

\begin{tabular}{|c|c|c|}
\hline No & Agenda Pelatihan. & Jadwal Relatihan. \\
\hline 1 & 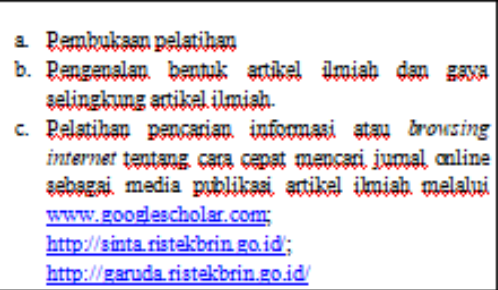 & $\begin{array}{l}\text { Senin, } 12 \text { Qlatober } 2020 \\
\text { Puknl } 15.00 \text { WIB }\end{array}$ \\
\hline 2 & 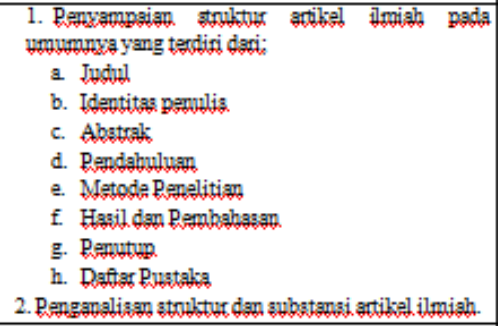 & $\begin{array}{l}\text { Rabu, } 14 \text { Qktober } 2020 \\
\text { Rulul } 14.00 \text { WIB }\end{array}$ \\
\hline 3 & Relatihan membuat judul dan identitas perulis & $\begin{array}{l}\text { Jumat, } 16 \text { Oldtober } 2020 \\
\text { Pulphl } 09.00 \text { WIB }\end{array}$ \\
\hline 4 & Polatiham parnlisan pendiguluan & $\begin{array}{l}\text { Senin, } 19 \text { Qktober } 2020 \\
\text { Pullul } 14.00 \text { WIB }\end{array}$ \\
\hline 5 & Pelatiham peruliam metode penelitian & $\begin{array}{l}\text { Rabu, } 21 \text { Qlatober } 2020 \\
\text { Pukpll } 14.00 \text { WIB }\end{array}$ \\
\hline 6 & Delatiham penulisan hasil dan permbahasan & $\begin{array}{l}\text { Jumgt, } 23 \text { Qhtober } 2020 \\
\text { Pullul } 10.00 \text { wIB }\end{array}$ \\
\hline 7 & 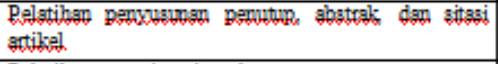 & $\begin{array}{l}\text { Senin, } 26 \text { Qltober } 2020 \\
\text { Pulply } 14.00 \text { WIB } \\
\end{array}$ \\
\hline 8 & Relatiham meregiater jumal. & \begin{tabular}{|l} 
Rabu. 28 Oltober 2020 \\
Puluml 14.00 WIB \\
\end{tabular} \\
\hline 9 & Pelstihan mensubmit artikel. & $\begin{array}{l}\text { Jumat, } 30 \text { Oltober } 2020 \\
\text { Pplypl } 15.00 \text { WIB }\end{array}$ \\
\hline 10 & 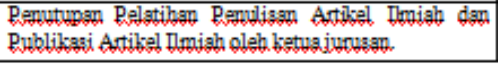 & $\begin{array}{l}\text { Selase, } 3 \text { November } 2020 \\
\text { Pulpul } 14.30\end{array}$ \\
\hline
\end{tabular}

\section{2) Rancangan Pelatihan}

Gagasan pemecahan isu tersebut, model pelatihan yang digunakan adalah model sistem pelatihan. Model sistem tersebut terdiri dari tahap berikut ini:

a. Analisis dan identifikasi; mengidentifikasikan kebutuhan pelatihan. Dalam konteks pelatihan ini, kebutuhan pelatihan adalah kemampuan menulis artikel mahasiswa dan cara mempublikasi artikel ilmiah, sampai artikel dapat disubmit.

b. Merancang; mendesain pelatihan untuk memenuhi kebutuhan yang telah diidentifikasi.

c. Mengembangkan; dalam tahap ini, dilakukan penyusunan daftar kegiatan atau program pelatihan dan penyediaan materi pelatihan.

d. Penerapan; tahap ini adalah bagian tersuli. Bagian ini menerapkan program yang telah disusun di dalam pelatihan.

e. Evaluasi; tahap mengevaluasi setiap fase untuk memastikan program telah terlaksana

\section{Hasil Pengabdian}

Kegiatan dalam aktualisasi ini adalah kegiatan pelaksanaan pelatihan penulisan artikel ilmiah dan publikasi artikel ilmiah. Kegiatan ini dilaksanakan dari tanggal 10 30 Oktober 2020. Seluruh tahapan di dalam kegiatan ini dilaksanakan dengan bahasa Indonesia yang jelas dan sopan. Selain itu, 
pelaksanaan kegiatan ini bersifat konsiten dan disiplin terhadap jadwal dan agenda yang telah dirumuskan. Selanjutnya, kegiatan ini seluruhnya dilaksanakan secara daring.

Berkaitan dengan uraian tersebut, berikut ini adalah tahapan-tahapan kegiatan kelima dalam aktualisasi ini.

\section{Pelaksanaan overview Pelatihan dan Materi Penulisan Artikel Ilmiah kepada Peserta melalui WA Grup}

Pelaksanaan overview pelatihan dan materi penulisan artikel ilmiah kepada seluruh mahasiswa yang mengikuti pelatihan melalui WA Group dengan bahasa yang sopan pada tanggal 12 Oktober 2020. Namun, pada tanggal 9 Oktober dan 10 Oktober 2020, peserta pelatihan telah diberikan pengarahan dalam kegiatan sosialisasi pelatihan. Di dalam pengarahan tersebut dijelaskan alat pendukung yang harus disiapkan, seperti ATK dan Laptop.

\section{Pelaksanaan Pelatihan Penulisan Artikel Ilmiah dan Publikasi Artikel Ilmiah}

Tahapan kedua dalam pelaksanaan kegiatan kelima merupakan tahapan inti dari secara keseluruhan kegiatan aktualisasi. Tahapan ini dilaksanakan pada tanggal 1230 Oktober 2020 dilaksanakan pelatihan menulis artikel ilmiah dengan penuh tanggung jawab, konsisten, dan disiplin terhadap waktu selama 9 pertemuan dalam 3 minggu dengan bahasa Indonesia yang sopan dan jelas sehingga menghasilkan pelatihan yang berorientasi kepada mutu. Setiap pertemuan terdiri dari 2 JP. Pelatihan dilakukan kepada 29 peserta yang merupakan mahasiswa tingkat IV Jurusan
Teknik Elektro Politeknik Negeri Lhokseumawe.

Pada setiap pertemuan mahasiswa diberikan motivasi bahwa mahasiswa pasti bisa mempraktikkan bahan pelatihan karena pada dasarnya setiap mahasiswa memiliki kemampuan berbahasa yang baik. Di dalam pertemuan, diberikan kesempatan mahasiswa untuk langsung mempraktikkan bahan yang telah dipelajari. Ada beberapa mahasiswa yang harus ditunjuk, namun banyak pula yang secara sukarela meminta menampilkan hasil pekerjaannya di dalam zoom.

Saat peserta menampilkan pekerjaannya, diberikan arahan kepada mahasiswa hal yang harus diperbaiki atau ditambahi. Selain itu, diberikan pula pujian kepada peserta ketika peserta dapat mengerjakan tugas praktiknya. Di dalam pelatihan selama tiga minggu tersebut, juga dilakukan komunikasi dengan peserta pelatihan melalui pesan pribadi untuk menyempurnakan hasil pelatihan setiap pertemuan di luar jam pelajaran melalui pesan teks pribadi.

Selanjutnya, setiap akhir pertemuan, diberikan bahan praktik yang selanjutnya dievaluasi baik langsung melalui WA Grup atau melalui pesan teks pribadi atau chat pribadi. Bahan praktik tersebut dikumpul melalui WA Grup yang bertujuan agar memudahkan dalam pendataan hasil pekerjaan peserta.

Secara spesifik, pelaksanaan pelatihan selama sembilan pertemuan terdiri dari pelatihan berikut ini:

\section{a. Pelatihan pengenalan bentuk artikel ilmiah dan gaya selingkung artikel ilmiah}


Di dalam pertemuan pertama ini, peserta pelatihan diperkenalkan bentuk artikel ilmiah secara umum yang terdiri dari; pendahuluan, metode penelitian, hasil dan pembahasan, kesimpulan dan saran, serta sumber referensi. Selanjutnya, diperkenalkan pula beberapa gaya selingkung artikel ilmiah dari berbagai jurnal ilmiah.

b. Pelatihan pencarian informasi atau browsing internet tentang cara cepat mencari jurnal online

Topik lain yang diajarkan di dalam pelatihan ini adalah pencarian artikel ilmiah melalui www.googlescholar.com; http://sinta.ristekbrin.go.id/; dan http://garuda.ristekbrin.go.id/. Peserta pelatihan diajarkan bagaimana menelusuri jurnal ilmiah dari sumber-sumber tersebut. Selanjutnya, peserta pelatihan diinstruksikan untuk mempraktikkan penelusuran jurnal ilmiah. Di dalam mempraktikkan tersebut, terdapat peserta yang langsung mengajukan diri untuk melakukan sharescreen zoom pekerjaannya. Namun, terdapat pula beberapa peserta pelatihan yang ditunjuk untuk menunjukkan hasil praktiknya. Di akhir pelatihan, peserta pelatihan diberikan tugas paraktik untuk mencari tiga judul artikel ilmiah beserta artikel ilmiah yang dituliskan di dalam formulir excel. Tugas tersebut dikumpul di dalam WA Grup untuk dievaluasi.

\section{c. Pelatihan pengenalan dan analisis struktur artikel ilmiah}

Topik ketiga yang diajarkan di dalam pelatihan adalah pengenalan struktur artikel ilmiah. Setelah peserta pelatihan mengenali struktur pelatihan, dilatih pula peserta untuk menaganalisis artikel ilmiah. Artikel ilmiah yang dianalisis adalah artikel yang pada pertemuan sebelumnya menjadi tugas latihan. Setelah peserta mampu menganalisis, peserta menyimpulkan bahwa seluruh struktur artikel ilmiah wajib ada di dalam artikel ilmiah. Walaupun demikian, penulisan artikel ilmiah harus mengikuti gaya selingkung yang terdapat di dalam jurnal ilmiah yang dituju.

\section{d. Pelatihan membuat judul, identitas penulis, dan pengenalan abstrak}

Topik selanjutnya adalah pelatihan membuat judul, identitas penulis, dan pengenalan bentuk abstrak. Peseta diajarkan bagaimana menentukan judul, yaitu berdasarkan topik yang dipilih. Selain itu, berdasarkan jenis penelitian apa yang akan diteliti. Peserta pelatihan selanjutnya membuat judul artikel ilmiah dengan sumber inspirasi dari makalah dan laporan PKL. Hal tersebut disebabkan mahasiswa belum melakukan proses pembimbingan dengan dosen pembimbing tugas akhir.

Setelah mampu membuat judul, peserta pelatihan diajarkan bagaimana membuat identitas penulis. Peserta diajarkan bahwa di dalam identitas penulis harus terdiri dari nama penulis, alamat email, dan afiliasi atau asal instansi. Dalam tahap pelatihan topik ini, peserta dapat langsung mengerjakan. Hal tersebut disebabkan menurut peserta, materi topik pembuatan identitas penulis tidak terlalu sulit. Selanjutnya, setelah peserta mampu membuat judul dan membuat identitas penulis, peserta diperkenalkan dengan abstrak. Namun, praktik pembuatan abstrak dilakukan setelah materi pelatihan penutup atau kesimpulan dan saran.

\section{e. Pelatihan membuat pendahuluan}


Topik selanjutnya yang diberikan pelatihan adalah pembuatan pendahuluan. Di dalam pelatihan penulisan pendahuluan, dilatih untuk mengetahui struktur pendahuluan pada umumnya, yaitu; latar belakang, urgensi, dan tujuan penelitian atau penulisan. Dijelaskan pula bahwa di dalam beberapa jurnal ilmiah, pendahuluan disatukan dengan tinjauan pustaka. Selanjutnya, di dalam pelaksanaan pelatihan topik tersebut, peserta pelatihan antusias dalam mempraktikkan menulis pendahuluan. Hal tersebut disebabkan pendahuluan di dalam artikel ilmiah pada dasarnya sejalan dengan pendahuluan dalam tugas akhir.

\section{f. Pelatihan membuat metode penelitian}

Topik penyusunan metode penelitian pada dasarnya adalah topik yang harus lebih ekstra sabar dalam memaparkan materi dan mengarahkan pekerjaan peserta. Peserta harus dijelaskan terlebih dahulu dari jenis penelitian, data dan sumber data, sampai teknik analisis data. Walaupun demikian, dengan kesabaran yang tinggi, peserta pelatihan dapat membuat metode penelitian artikel ilmiah. Ilmu yang diperoleh tersebut pada dasarnya membantu peserta dalam proses penyelesaian tugas akhir.

\section{g. Pelatihan membuat hasil dan pembahasan}

Topik selanjutnya adalah membuat hasil dan pembahasan. Di dalam tahap ini, proses pelatihan tidak terlalu sulit. Hal tersebut disebabkan pada dasarnya peserta telah menulis hasil dan pembahasan di dalam makalah atau laporan pratik lapangan. Walaupun demikian, peserta pelatihan tetap diajarkan bagaimana menyusun hasil dan pembahasan berdasarkan jenis artikel ilmiah yang mereka buat. Banyak pula, peserta pelatihan yang membuat hasil dan pembahasan murni dari awal. Hal tersebut disebabkan karena jenis artikel ilmiah yang dibuat peserta adalah hasil artikel ulasan dan kajian teori.

\section{h. Pelatihan membuat kesimpulan dan saran}

Topik kedelapan yang diajarkan di dalam pelatihan adalah pembuatan kesimpulan dan saran. Topik tersebut dapat dengan mudah diselesaikan. Hal tersebut disebabkan peserta pelatihan selalu ditekankan bahwa kesimpulan harus sejalan dengan tujuan atau rumusan masalah, hasil dan pembahasan, serta abstrak.

\section{i. Pelatihan membuat daftar pustaka atau sitasi untuk menghindari plagiasi}

Topik selanjutnya yang diajarkan adalah pembuatan daftar pustaka dan sitasi. Dalam pelatihan tersebut, peserta langsung mempraktikkan bagaimana mensitasi artikel ilmiah ke dalam sumber referensi dengan model APA dan MLA. Selain itu, dijelaskan pula bagaimana menyusun daftar pustaka yang berasal dari buku, skripsi, koran, bahkan artikel popular.

\section{j. Pelatihan meregister dan mensubmit artikel ilmiah}

Pertemuan ini dilatih oleh Kepala Editor Jurnal Bahasa Indonesia Prima dengan topik Pelatihan Registrasi dan Submit Artikel Ilmiah ke Jurnal Ilmiah. Hal tersebut bertujuan agar peserta pelatihan dapat memperoleh ilmu secara langsung dengan pengurus jurnal ilmiah. Tentunya, hal tersebut setelah mendapatkan persetujuan dari mentor sekaliguas Ketua 
Jurusan Teknik Elektro Politeknik Negeri Lhokseumawe.

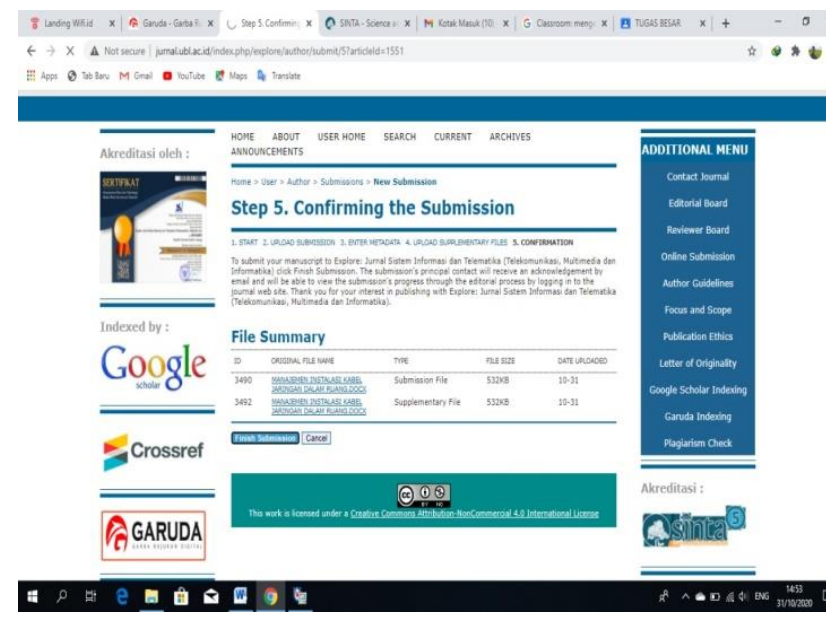

Gambar 1 Bukti Keberhasilan Peserta Pelatihan dalam Mensumbit Artikel Ilmiah

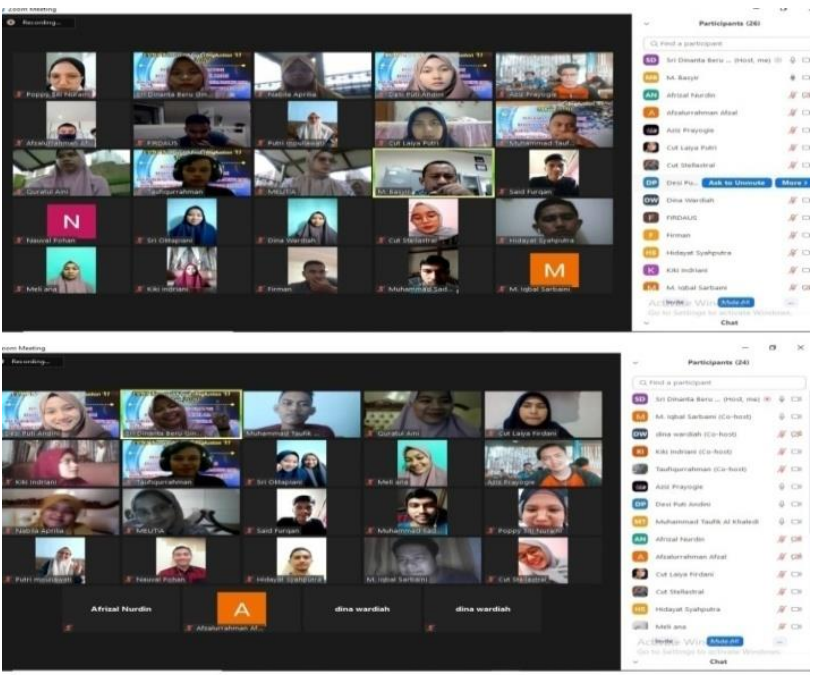

Gambar 2 Cuplikan Pelaksanaan Pelatihan

\section{Evaluasi Pelatihan secara Jelas, tidak Memihak, dan Dapat Dipercaya}

Setiap akhir pertemuan, selalu dilakukan evaluasi pelatihan secara jelas, tidak memihak, dan dapat dipercaya. Evaluasi dilakukan dengan cara mengkoreksi pekerjaan mahasiswa. Jika terdapat kesalahan dalam pekerjaan mahasiswa atau peserta, maka diberikan arahan dan bantuan hingga peserta dapat menyelesaikan bahan praktiknya.

Pada pertemuan kedelapan, setelah mendata dan menyeleksi artikel ilmiah yang dapat disubmit ke jurnal ilmiah secara jelas, tidak memihak, dan dapat dipercaya. Dari 29 peserta yang mengikuti pelatihan, terdapat 24 artikel yang berasal dari 26 peserta yang dapat disubmit ke dalam Jurnal Ilmiah. Selanjutnya, peserta mengirimkan bukti register dan submit artikel ke dalam WA Grup.

4. Pendataan dan Penyeleksian Artikel Ilmiah yang dapat Disubmit

Tahap terakhir dari keguatan kelima adalah pendataan dan penyeleksian artikel ilmiah. Pendataan ini sejalan dengan evaluasi tugas pelatihan peserta. Pendataan ini dilakukan setelah pertemuan kedelapan pelatihan, yaitu tanggal 28-29 Oktober 2020 . Setelah dilakukan pendataan, terdapat 24 artikel yang dapat disubmit ke dalam jurnal ilmiah. 24 artikel tersebut berasal dari 26 peserta. Hal tersebut disebabkan terdapat dua artikel yang ditulis oleh dua peserta. Hal tersebut tidak menyalahi dari output pelatihan.

Atas dasar itu, berikut ini adalah daftar nama mahasiswa dan jurnal yang dituju untuk mensubmit artikel ilmiah.

1) Taufiqurrahman, Poppy Siti Nuraini (Jurnal Argo industri perkebunanPolinela)

2) Cut Laiya Putri Firdani (Jurnal Elektro dan Telekomunikasi-Universitas Telkom)

3) Desi Puti Andini (Jurnal Agro Universitas Islam Negeri Sunan Gunung Djati) 
4) Muhammad Taufik Al Khaledi (Jurnal Sistem Informasi dan Telematika Universitas Bandar Lampung)

5) Tasya Humaira (Jurnal Teknik Elektro dan Informatika - universitas muhammadiyah Gresik

6) Odi Setiawan (Jurnal elektronika telekomunikasi terapan- Universitas Telkom)

7) Aziz Prayogie (Jurnal Elektronika Telekomunikasi Terapan- Universitas Telkom)

8) Quratul aini (Jurnal Elektro Telekomunikasi Terapan- Universitas Telkom)

9) Sri oktapiani (Jurnal Elektro Telekomunikasi Terapan- Universitas Telkom)

10) Hendri usmantri (Jurnal Elektro Telekomunikasi Terapan- Universitas Telkom)

11) Rahmah Maulida (Jurnal Telekomunikasi dan Komputer, Universitas Mercu Buana)

12) Putri moulia wati (Jurnal Elkomikauniversitas itenas)

13) Cut Stellastral (Jurnal Elektro dan Telekomunikasi Terapan- Universitas Telkom)

14) Muhammad Rizky (Jurnal Elektronika Telekomunikasi Terapan- Universitas Telkom)

15) Dina wardiah (jurnal elektro dan telekomunikasi Terapan- Universitas Telkom)

16) Zulfachri (Jurnal Penerapan Teknologi dan Pembelajaran-Universitas Negeri Semarang )
17) Firman dan Firdaus (Jurnal Ilmiah Pengabdian kepada Masyarakat- Institut Pertanian Bogor)

18) Afrizal Nurdin(Jurnal ilmiah tehnik elektro-Universitas diponogoro)

19) Rehan rozanna (Jurnal Buletin Ilmiah Sarjana Teknik Elektro - Universitas Ahmad Dahlan)

20) Meutia (jurnal telekomunikasi dan komputer, universitas mercu buana)

21) Annisa (jurnal Teknik Elektro dan Informatika -universitas muhammadiyah gresik)

22) Fauzul Akbar (Jurnal Teknik Informatika - Politeknik Pos Indonesia)

23) Nabila aprilia (Jurnal telekomunikasi dan komputer-Universitas Mercu Buana)

24) Muhammad iqbal sarbaini (Jurnal elektro telekomunikasi terapan )

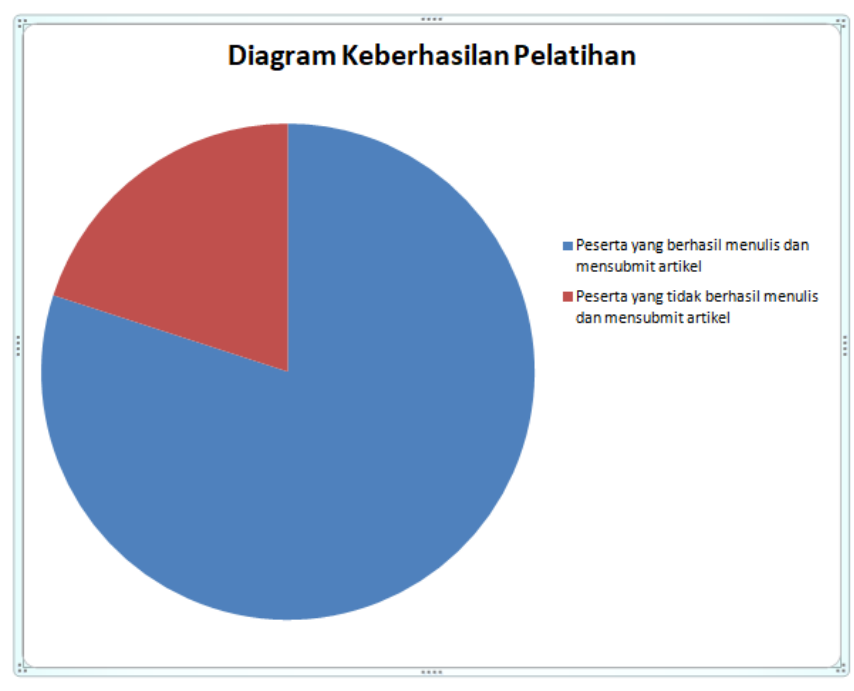

\section{Simpulan}

Kegiatan Pelatihan Penulisan Artikel Ilmiah dan Publikasi Artikel Ilmiah telah berhasil dengan indikator, yaitu; jumlah peserta yang mampu mensubmit artikel imiah ke jurnal nasional lebih dari $80 \%$ dari jumlah peserta. Dengan rincian 
26 peserta yang berhasil menulis dan mensubmit 24 artikel ilmiah dari 29 peserta pelatihan. Peserta pelatihan yang tidak berhasil disebabkan tidak mengikuti keseluruhan agenda pelatihan.

\section{Daftar Pustaka}

Silaswati, Diana. (2018). "Pentingnya Penentuan Topik dalam Penulisan Karya Ilmiah pada Bidang Ilmu Akuntansi”. Akurat : Jurnal Ilmiah Akuntansi. Vol 9 (1) h 81-88.

Slameto. (2016). "Penulisan Artikel Ilmiah Hasil Penelitian Tindakan Kelas".Scholaria. Vol 6 (2) h 45-67.
Syahfitri, Dian. 2019. Bahasa Indonesia Dasar. Yogyakarta: Arti Bumi Intaran.

Telaumbanua, Sadieli dan Sri Dinanta Beru Ginting. 2019. Kompetensi Berekspresi 1 Keterampilan Menulis bagi (Mahasiswa Calon) Guru. Ponorogo: Uwais Inspirasi Indonesia.

Universitas Pendidikan Indonesia. 2007. Pedoman Penulisan Karya Ilmiah. Bandung: UPI Press.

Widayoko, Agus. 2020. Menulis Artikel Ilmiah dan Esai. Bandung: Yrama Widya. 